\title{
ANALISIS PENGARUH PERBEDAAN WAKTU PERENDAMAN BERAS KETAN TERHADAP KUALITAS PRODUK RENGGINANG MENGGUNAKAN METODE ANOVA DAN PERBANDINGAN EKSPONENSIAL (MPE)
}

\author{
IRAWAN $^{1)} \&$ CHRISWAHYUDI ${ }^{2)}$ \\ 1,2) Program Studi Teknik Industri, Institut Sains dan Teknologi Al Kamal \\ Jl. Raya Al Kamal No. 2 Kedoya Selatan, Kebon Jeruk, \\ Jakarta Barat, DKI Jakarta 11520 \\ Email: irawan.faitur@gmail.com, ${ }^{1)}$ chrismb73@gmail.com ${ }^{2)}$
}

\begin{abstract}
ABSTRAK
Rengginang merupakan salah satu makanan tradisional Indonesia khas Indonesia yang dibuat dari bahan beras ketan putih atau hitam. UMKM Teh Lala merupakan salah satu Usaha Mikro, Kecil, Menengah yang ada di garut, UMKM The Lala memproduksi rengginang yang berbentuk bulat, dan terdapat tiga varian rengginang yang dibuat yaitu rengginang beras ketan putih polos, beras ketan putih terasi, dan rengginang beras ketan hitam. Dengan semakin banyaknya bisnis usaha yang berkembang dengan sangat pesat, terutama dibidang makanan, untuk meningkatkan kepercayaan konsumen diperlukan adanya kestabilan kualitas dalam memproduksi rengginang tersebut baik dari segi warna, rasa dan kerenyahan rengginang tersebut. Tujuan penelitian ini adalah untuk mengetahui pengaruh dan perbandingan perendaman beras ketan yang tepat yang akan digunakan sebagai standar untuk pembuatan rengginang yang berkualitas menggunakan Metode Perbandingan Eksponensial (MPE). Metode ANOVA satu arah digunakan untuk mengetahui apakah perbedaan lama perendaman berpengaruh terhadap kerenyahan. Dari hasil tersebut, dalam menentukan produk terbaik yang dipilih berdasarkan variabel warna, kerenyahan, dan rasa dengan menggunakan Metode Perbandingan Eksponensial (MPE). Dari hasil pengukuran kerenyahan rengginang dengan 3 waktu yaitu 6 jam, 9 jam, dan 12 jam dengan replikasi 10 kali didapatkan hasil bahwa lama perendaman berpengaruh terhadap tekstur rengginag. Uji lanjutan setelah ANOVA yaitu uji Tukey menunjukkan bahwa lama perendaman berpengaruh signifikan pada analisa tekstur pada lama perendaman 6 jam, 9 jam, dan 12 jam. Hasil dari perhitungan MPE berdasakan variabel warna, rasa, dan kerenyahan didapatkan lama perendaman terbaik yaitu 6 jam, karena mempunyai nilai MPE paling tinggi yaitu 596.234,01.
\end{abstract}

Kata Kunci: beras ketan, rengginang, ANOVA, MPE.

\begin{abstract}
Rengginang is one of Indonesian traditional foods made from white or black glutinous rice. Lala Tea SMEs is one of the SMEs in Garut that produces round rengginang, and there are three variants of rengginang that are made, namely plain white glutinous rice rengginang, white glutinous glutinous rice, and black glutinous rice rengginang. With the increasing number of business businesses that are developing very rapidly, especially in the field of food, to increase consumer confidence requires the stability of quality in producing the Rengginang both in terms of color, taste and crispness of the Rengginang. The
\end{abstract}


purpose of this study was to determine the effect and comparison of appropriate glutinous rice immersion which will be used as a standard for the manufacture of quality rengginang using the Exponential Comparison Method (MPE). Oneway ANOVA method is used to determine whether the difference in soaking time affects crispness. From these results to determine the best product selected based on the variable color, crispness, and taste using the Exponential Comparison Method (MPE).From the measurement results of crispy crispness with 3 times, namely 6 hours, 9 hours, and 12 hours with 10 times replication, it was found that the length of soaking affected the texture of Rengginag. Followup test after ANOVA, Tukey's test, showed that immersion duration had a significant effect on texture analysis on soaking time of 6 hours, 9 hours and 12 hours. The results of the MPE calculation based on the color, taste, and crispness variables obtained the best soaking time is 6 hours, because it has the highest MPE value of 596,234.01.

Keywords: Glutinous Sticky Rice, Rengginang, Anova, MPE.

\section{PENDAHULUAN}

Beras ketan (Oryza Sativa L var. Glutinosa) merupakan tanaman yang berasal dari Asia yang kini sudah tersebar luas ke seluruh dunia, termasuk Indonesia. Saat ini beras ketan banyak terdapat di indonesia dengan jumlah produksi sekitar 42.000 ton pertahun. Beras ketan adalah jenis beras yang warnanya lebih putih dari beras lainnya dan memiliki ukuran yang lebih besar dan keras.

Beras ketan putih di indonesia cukup melimpah dan produktivitasnya setiap tahun meningkat. Berdasarkan data dari Badan Pusat Statistik diketahui bahwa tahun 2008 sampai tahun 2012, jumlah ketersediaan beras meningkat daru 60.325.925 ton menjadi 69.056.126 ton. Permintaan beras ketan banyak terdapat pada sektor makanan ringan seperti kue opak, rengginang, dan makanan lainnya. (Dinas Pariwisata dan Kebudayaan Provinsi Jawa Barat, 2012). Beras ketan putih mengandung energi sebesar 362 kilo kalori, protein 6,7 gram, karbohidrat 79,4 gram, lemak 0,67 gram, kalsium 12 gram, fosfor 148 miligram, zat besi 1 miligram dan vitamin B1 sebanyak 0,16 miligram. Hasil tersebut didapat dari melakukan penelitian terhadap 100 gram beras ketan, dengan jumlah yang dapat dimakan sebanyak $100 \%$.

Rengginang merupakan cemilan yang dapat dikonsumsi sehari-hari masyarakat Indonesia dari berbagai kalangan masyarakat, dari anak-anak sampai dewasa maupun masyarakat ekonomi rendah hingga tinggi. Kabupaten Garut merupakan daerah terluas kedua dari 27 kabupaten di Provinsi Jawa
Barat (sumber: https://id.wikipedia.org/wiki/ Jawa_Barat). Banyak UMKM yang memiliki potensi untuk pengembangan industri dikabupaten ini, baik industri kecil maupun besar serta menengah, baik itu berupa makanan ringan, minuman, dan tekstil yang sedang berkembang dan terus berkembang.

UMKM Teh Lala merupakan salah satu UMKM yang ada di garut yang memproduksi rengginang yang berbentuk bulat, dan terdapat tiga varian rengginang yang dibuat yaitu rengginang beras ketan putih polos, beras ketan putih terasi, dan rengginang beras ketan hitam. Produk-produk yang sudah dibuat kemudian didistribusikan beberapa distributor dan pembeli langsung. Dengan semakin banyaknya bisnis usaha yang berkembang dengan sangat pesat, terutama dibidang makanan, untuk meningkatkan kepercayaan konsumen diperlukan adanya kestabilan kualitas dalam memproduksi rengginang tersebut baik dari segi warna, rasa dan kerenyahan rengginang tersebut. Berdasarkan informasi dari lapangan bahwa yang menjadi pengaruh dari ketiga variabel diatas (warna, rasa, dan kerenyahan) salah satunya terdapat pada proses pembuatan rengginang yaitu waktu perendaman beras ketan sebelum beras ketan tersebut diolah lebih lanjut. Dengan adanya waktu perendaman yang sesuai dan nantinya akan dijadikan standar diharapkan mampu meningkatkan kepercayaan konsumen terhadap produk rengginang pada UMKM Teh Lala sehingga penjualan pun ikut meningkat. 


\section{METODE PENELITIAN \\ 1. Pengumpulan Data}

Data-data yang digunakan selama penelitian ini dilakukan adalah sebagai berikut:

a) Data Primer

Data yang didapatkan secara langsung oleh peneliti sesuai dengan latar belakang atau permasalahan yang dialami oleh perusahaan. Data primer yang digunakan dalam penelitian ini merupakan data wawancara dan riset lapangan secara langsung.

\section{b) Data Sekunder}

Data yang didapatkan dari buku, jurnal, serta materi kuliah yang diperlukan pada penelitian ini. Data Sekunder yang digunakan dalam penelitian ini adalah Metode ANOVA dan Metode Perbandingan Eksponensial (MPE).

\section{Metode Anova (Analysis of Variance)}

Model perancangan eksperimen yang digunakan untuk mengolah data dengan Hipotesa sebagai berikut:

$\mathrm{H}_{0}=$ Lama perendaman beras ketan mempengaruhi hasil uji kekerasan pada rengginang

$\mathrm{H}_{1}=$ Lama perendaman beras ketan tidak mempengaruhi hasil uji kekerasan pada rengginang

Dengan ketentuan "Jika $\mathrm{F}_{0}>\mathrm{F}$ Tabel " maka tolak $\mathrm{H}_{0}$ (terima $\mathrm{H}_{1}$ ) dan $\alpha=0.05$ ”

Hasil analisa kekerasan rengginang menggunakam 3 waktu lama perendaman yang berbeda dan replikasi sebanyak 10 kali maka diperoleh data sebagai berikut:
Tabel 1. Data Replikasi Hasil Analisa Kerenyahan

\begin{tabular}{|c|c|c|c|}
\hline $\begin{array}{c}\text { Lama perendaman } \\
\text { (jam) }\end{array}$ & Urut Penomoran & Replikasi & Kerenyahan (KG/Force) \\
\hline 9 & 11 & 1 & 608.41 \\
\hline 9 & 13 & 3 & 607.17 \\
\hline 9 & 19 & 9 & 609.02 \\
\hline 6 & 1 & 1 & 614.18 \\
\hline 6 & 4 & 4 & 611.19 \\
\hline 9 & 20 & 10 & 606.55 \\
\hline 12 & 28 & 8 & 602.10 \\
\hline 6 & 6 & 6 & 614.10 \\
\hline 12 & 30 & 10 & 603.15 \\
\hline 12 & 22 & 2 & 603.11 \\
\hline 6 & 2 & 2 & 613.15 \\
\hline 12 & 21 & 1 & 602.64 \\
\hline 12 & 27 & 7 & 601.00 \\
\hline 12 & 29 & 9 & 604.25 \\
\hline 6 & 5 & 5 & 613.62 \\
\hline 6 & 7 & 7 & 615.12 \\
\hline 9 & 14 & 4 & 606.30 \\
\hline 6 & 9 & 9 & 615.60 \\
\hline 12 & 23 & 3 & 602.72 \\
\hline 6 & 3 & 3 & 612.17 \\
\hline 9 & 18 & 8 & 608.53 \\
\hline 6 & 8 & 8 & 610.10 \\
\hline 12 & 24 & 4 & 601.15 \\
\hline 9 & 15 & 5 & 607.10 \\
\hline 6 & 10 & 10 & 613.12 \\
\hline 12 & 25 & 5 & 605.30 \\
\hline 9 & 16 & 6 & 608.24 \\
\hline 9 & 12 & 2 & 606.15 \\
\hline 12 & 26 & 6 & 601.09 \\
\hline 9 & 17 & 7 & 609.17 \\
\hline
\end{tabular}

Perhitungan Data dengan Metode Anova.

Analisa variansi yang dilakukan terhadap data yang diperoleh dapat dilihat pada Tabel RCBD. Pengolahan data yang diperoleh dengan menggunakan rumus perhitungan manual dan dengan software minitab.

Tabel 2. Data ANOVA Hasil Uji Kerenyahan

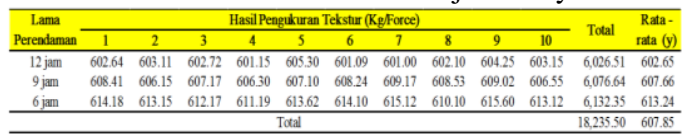

Tabel 3. Tiper Data ANOVA Satu Arah

\begin{tabular}{|c|c|c|c|c|c|c|}
\hline Replikasi & $\begin{array}{c}\text { Lama } \\
\text { Perendaman }\end{array}$ & Penomoran & $\boldsymbol{y}_{i j}$ & $y_{. .}$ & $y_{i j}-y$. & $\begin{array}{l}\left(y_{i j}\right. \\
-y . .)^{2}\end{array}$ \\
\hline 1 & 12 & 1 & 602.64 & 607.85 & -5.21 & 27.14 \\
\hline 2 & 12 & 2 & 603.11 & 607.85 & -4.74 & 22.47 \\
\hline 3 & 12 & 3 & 602.72 & 607.85 & -5.13 & 26.32 \\
\hline 4 & 12 & 4 & 601.15 & 607.85 & -6.70 & 44.89 \\
\hline 5 & 12 & 5 & 605.30 & 607.85 & -2.55 & 6.50 \\
\hline 6 & 12 & 6 & 601.09 & 607.85 & -6.76 & 45.70 \\
\hline 7 & 12 & 7 & 601.00 & 607.85 & -6.85 & 46.92 \\
\hline 8 & 12 & 8 & 602.10 & 607.85 & -5.75 & 33.06 \\
\hline 9 & 12 & 9 & 604.25 & 607.85 & -3.60 & 12.96 \\
\hline 10 & 12 & 10 & 603.15 & 607.85 & -4.70 & 22.09 \\
\hline 1 & 9 & 11 & 608.41 & 607.85 & 0.56 & 0.31 \\
\hline 2 & 9 & 12 & 606.15 & 607.85 & -1.70 & 2.89 \\
\hline 3 & 9 & 13 & 607.17 & 607.85 & -0.68 & 0.46 \\
\hline 4 & 9 & 14 & 606.30 & 607.85 & -1.55 & 2.40 \\
\hline 5 & 9 & 15 & 607.10 & 607.85 & -0.75 & 0.56 \\
\hline 6 & 9 & 16 & 608.24 & 607.85 & 0.39 & 0.15 \\
\hline 7 & 9 & 17 & 609.17 & 607.85 & 1.32 & 1.74 \\
\hline 8 & 9 & 18 & 608.53 & 607.85 & 0.68 & 0.46 \\
\hline 9 & 9 & 19 & 609.02 & 607.85 & 1.17 & 1.37 \\
\hline 10 & 9 & 20 & 606.55 & 607.85 & -1.30 & 1.69 \\
\hline 1 & 6 & 21 & 614.18 & 607.85 & 6.33 & 40.07 \\
\hline 2 & 6 & 22 & 613.15 & 607.85 & 5.30 & 28.09 \\
\hline 3 & 6 & 23 & 612.17 & 607.85 & 4.32 & 18.66 \\
\hline 4 & 6 & 24 & 611.19 & 607.85 & 3.34 & 11.16 \\
\hline 5 & 6 & 25 & 613.62 & 607.85 & 5.77 & 33.29 \\
\hline 6 & 6 & 26 & 614.10 & 607.85 & 6.25 & 39.06 \\
\hline 7 & 6 & 27 & 615.12 & 607.85 & 7.27 & 52.85 \\
\hline 8 & 6 & 28 & 610.10 & 607.85 & 2.25 & 5.06 \\
\hline 9 & 6 & 29 & 615.60 & 607.85 & 7.75 & 60.06 \\
\hline \multirow[t]{2}{*}{10} & 6 & 30 & 613.12 & 607.85 & 5.27 & 27.77 \\
\hline & & Total & & & & 616.18 \\
\hline
\end{tabular}


Dari penelitian ini terdapat 1 faktor yaitu lama perendaman beras ketan. 3 Level yaitu 6 jam, 9 jam, dan 12 jam. Dan replikasi sebanyak 10 kali ditiap levelnya.

$$
\mathrm{a}=3, \mathrm{n}=10, \mathrm{~N}=30
$$

$\mathrm{SS}$ treatments $=\mathrm{n} \sum_{i=1}^{a}\left(\bar{y}_{i}-\bar{y} . .\right)^{2}$

$$
=10\left\{(602.65-607.85)^{2}+(607.66-\right.
$$

$$
\left.607.85)^{2}+(613.24-607.85)^{2}\right\}
$$

$=10\left\{(-5.20)^{2}+(-0.19)^{2}+(5.38)^{2}\right\}$

$=560.62$

$$
\begin{aligned}
\text { SS Total } & =\sum_{i=1}^{a} \sum_{j=1}^{n}\left(y_{i j}-\bar{y}_{. .}\right)^{2} \\
& =616.18 \\
\text { SS Error } & =\text { SS Total }- \text { SS treatments } \\
& =616.18-560.62 \\
& =55.56
\end{aligned}
$$

Tabel 3.Tabel ANOVA Satu Arah Hasil Uji Kerenyahan Rengginang

\begin{tabular}{lrrrc}
\hline Source Of Varian & $\begin{array}{r}\text { Sum of } \\
\text { Squares }\end{array}$ & $\begin{array}{c}\text { Degrees of } \\
\text { Freedom }\end{array}$ & $\begin{array}{c}\text { Mean } \\
\text { Square }\end{array}$ & F $_{\mathbf{0}}$ \\
\hline Lama Perendaman & 560.62 & 2.00 & 280.31 & 136.22 \\
Error & 55.56 & 27.00 & 2.06 & \\
Total & 616.18 & 29.00 & & \\
\hline
\end{tabular}

Dari tabel Anova satu arah hasil uji kerenyahan diatas, maka dapat diperoleh nilai untuk $\mathrm{F}_{0}=136.22$, sedangkan nilai dari $\mathrm{F}$ Tabel di atas diperoleh dari melihat Tabel Nilai DIstribusi F, dengan ketentuan sebagai berikut:

$$
\begin{aligned}
\mathrm{F} \text { tabel } & =\mathrm{F} \alpha ; \mathrm{a}-1 ;(\mathrm{N}-\mathrm{a}) \\
& =\mathrm{F} 0.05 ; 2 ; 27 \\
& =3,35
\end{aligned}
$$

Sehingga diperoleh nilai $\mathrm{F}$ tabel $=3.35$, dan nilai $\mathrm{F}_{0}=136.22$, maka untuk kesimpulan yang pertama bahwa nilai $\mathrm{F}_{0}>\mathrm{F}$ Tabel, dengan begitu berarti tolak $\mathrm{H}_{0}$ (Terima $\mathrm{H}_{1}$ ) yaitu lama perendaman beras ketan mempengaruhi kerenyahan pada rengginang.

\section{Metode Perbandingan Eksponensial (MPE)}

Rasa merupakan parameter rengginang yang penting. Untuk mendapatkan rasa rengginang yang enak maka perlu diketahui lama perendaman beras ketan terbaik untuk menghasilkan rengginang yang terbaik yang dapat diterima oleh masyarakat. Untuk menguji hal tersebut dibuat 3 alternatif pilihan yang akan di panel oragnoleptik uji kesukaan oleh panelis terlatih kemudian dianalisa dengan metode perbandingan eksponensial (MPE).
Tabel 4. Hasil Perbandingan Bobot Kriteria Dengan Kepentinagn Kriteria

\begin{tabular}{cccc}
\hline & \multicolumn{3}{c}{ Kriteria } \\
\cline { 2 - 4 } Jenis Produk & Warna & Kerenyahan & Rasa \\
\cline { 2 - 4 } & 7 & 9 & 8 \\
\hline Sampel A & 3,224 & 4,229 & 4,472 \\
Sampel B & 3,464 & 3,464 & 3,722 \\
Sampel C & 3,000 & 2,711 & 3,464 \\
\hline
\end{tabular}

Perhitungan dengan rumus MPE sebagai berikut:

Total Nilai $\left(T N_{i}\right)=\sum_{j=1}^{m}\left(R K_{i j}\right)^{T K K_{j}}$

$\mathrm{TN}_{\mathrm{i}}=$ total nilai akhir dari alternatif ke $-\mathrm{i}$

$\mathrm{RK}_{\mathrm{ij}}=$ derajat kepentingan kriteria relatif

ke-j pada pilihan keputusan i

$\mathrm{TKK}_{\mathrm{j}}=$ derajat kepentingan kriteria relatif ke-j

$\mathrm{TKK}_{\mathrm{j}}>0 \mathrm{~m}=$ jumlah kriteria Keputusan

Nilai MPE akan didapat dari perhitungan sebagai berikut :

a) Alternatif 1 (Sampel A )

$$
\begin{aligned}
= & (3,224)^{7}+(4,229)^{9}+(4,472)^{8} \\
= & (3.620,47)+(432.652,45)+ \\
& (159.961,09) \\
= & 596.234,01
\end{aligned}
$$

b) Alternatif 2 (Sampel B)

$$
\begin{aligned}
= & (3,464)^{7}+(3,464)^{9}+(3,722)^{8} \\
= & (5.984,74)+(71.812,65)+ \\
& \quad(36.830,78) \\
= & 114.628,17
\end{aligned}
$$

c) Alternatif 3 (Sampel C )

$$
\begin{aligned}
& =(3,000)^{7}+(2,711)^{9}+(3.464)^{8} \\
& =(2.187,00)+(7.909,80)+(20.731,13) \\
& =(30.827,93)
\end{aligned}
$$

Tabel 5. Hasil Perhitungan dengan MPE

\begin{tabular}{lcc}
\hline \multicolumn{1}{c}{ Alternatif Keputusan } & Nilai MPE & Peringkat \\
\hline Lama Perendaman 6 jam & $\mathbf{5 9 6 . 2 3 4 , 0 1}$ & 1 \\
Lama perendaman 9 Jam & $\mathbf{1 1 4 , 6 2 8 . 1 7}$ & 2 \\
Lama Perendaman 12 Jam & $30.827,93$ & 3 \\
\hline
\end{tabular}

Jadi lama perendaman yang paling disukai dari kriteria warna kerenyahan dan rasa adalah 6 jam. Dikarenakan mempunyai nilai MPE yang paling besar yaitu 596.234,01.

\section{ANALISA PEMBAHASAN}

Data yang diperoleh dengan menggunakan rumus perhitungan pada pengujian kerenyahan dari 3 dosis lama perendaman beras ketan yang berbeda dengan replikasi sebanyak 10 kali diperoleh nilai $\mathrm{F}_{0}=136.22$ 
sedangkan nilai dari $\mathrm{F}$ tabel $=3.35$. Maka untuk analisa yang pertama bahwa nilai $\mathrm{F}_{0}$ > F tabel, dengan begitu berarti tolak $\mathrm{H}_{0}$ (terima $\mathrm{H}_{1}$ ) yaitu lama perendaman beras ketan mempengaruhi kerenyahan pada rengginang.

Dari hasil analisa ANOVA diketahui bahwa $\mathrm{H}_{0}$ ditolak, artinya bahwa dari variabel-variabel yang diuji, terdapat perbedaan yang signifikan. Untuk mengetahui variabel mana yang berbeda signifikan maka perlu dianalisa untuk lanjutan (post hoe). Analisa yang digunakan adalah metode Tukey atau sering disebut dengan uji beda nyata jujur HSD (Honestly Significant Difference), Uji ini disebut uji beda nyata karena uji ini untuk membandingkan mean tanpa perencanaan terlebih dahulu. Uji ini digunakan karena ukuran kelompok sama jenis pengujian yang digunakan adalah jumlah pada kelompok (T).

1. Data yang digunakan dalam perhitungan Tukey.

$\mathrm{k}=3$

$\mathrm{n}=10$

$\mathrm{N}=30$

$\mathrm{v}=27$

$\mathrm{T}_{1}=6026,51$

$\mathrm{T}_{2}=6076,64$

$\mathrm{T}_{3}=6132,35$

$\mathrm{MSe}=2,058$

$\alpha=0,05$

$\mathrm{q}_{(0,05)(3,27)}=3,506$

\section{Kriteria pengujian}

$B_{T}=\left(q_{(\alpha)(k, v)}\right) \sqrt{(n)(M S e)}$

Perlakuan berpengaruh signifikan terhadap hasil jika $\left|\sum \mathrm{T}_{\mathrm{i}}-\sum \mathrm{T}_{\mathrm{j}}\right| \geq \mathrm{B}_{\mathrm{T}}$

\section{Perhitungan Tukey}

$$
\begin{aligned}
& B_{T}=(3,506) \sqrt{(10)(2,058)} \\
& B_{T}=3,506 * 4.54=15,917
\end{aligned}
$$

\section{Perbandingan nilai jumlah dan kriteria}

Kriteria $=15,917$

Nilai jumlah:
a) $\left|\sum \mathrm{T}_{1}-\sum \mathrm{T}_{2}\right|=6026.51-6076.64$
$=50,13 \geq 15,917$
Signifikan
b) $\left|\sum \mathrm{T}_{\mathrm{i}}-\sum \mathrm{T}_{3}\right|=6026.51-6132.35$
$=105,84 \geq 15.917$
Signifikan

$$
\text { c) } \begin{aligned}
\left|\sum \mathrm{T}_{2}-\sum \mathrm{T}_{3}\right|= & 6076.64-6132.35 \\
= & 55,71 \geq 15.917 \\
& \text { Signifikan }
\end{aligned}
$$

Hasil perhitungan Tukey dinyatakan signifikan apabila selisih antara dua perlakuan yang dibandingkan lebih besar atau sama dengan nilai kriteria.

Dari perhitungan uji lanjutan Tukey diatas menunjukan bahwa pengaruh perbedaan kerenyahan rengginang pada perlakuan pertama, kedua, dan ketiga signifikan, berarti lama perendaman beras ketan selama 6 jam, 9 jam, dan 12 jam berpengaruh signifikan terhadap kerenyahan rengginang. Dari hasil perhitungan lanjutan metode Tukey didapatkan dosis lama perendaman beras ketan berpengaruh signifikan terhadap kualitas rengginang. Dikarenakan semua lama perendaman berpengaruh signifikan, maka lama perendaman terkecil yang diambil yaitu 6 jam.

Dalam pembuatan rengginang digunakan bahan baku utama yaitu beras ketan. Untuk mengetahui perbandingan lama perendaman yang tepat maka dilakukan panel organoleptic uji kesukaan kepada 4 panelis terlatih. Kriteria yang menjadi penilaian adalah warna, kerenyahan dan rasa. Ketiga kriteria ditentukan bobotnya berdasarkan keterkaitannya dengan mutu rengginang. Kriteria warna bobotnya 7 karena cukup berpengaruh terhadap mutu rengginang. Warna menjadi pertimbangan konsumen saat akan melihat rengginang yang akan dibeli. Kriteria kerenyahan bernilai 9 dikarenakan sangat berpengaruh terhadap mutu karena rengginang adalah identik dengan makanan ringan yang renyah, maka jika kerenyahan kerupuk tidak sesuai (keras/lembek) maka tidak sesuai dengan kriteria kebutuhan konsumen. Rasa berbobot 8 karena cukup berpengaruh. Rengginang biasa mempunyai rasa yang ringan tidak terlalu kuat dari segi citarasa, karena rengginang sering dijadikan sebagai kudapan pelengkap atau camilan ringan.

Alternatif dalam penentuan proses lama perendaman beras ketan ada tiga diantaranya yaitu:

a) Lama perendaman beras ketan selama 6 jam;

b) Lama perendaman beras ketan selama 9 jam; dan 
c) Lama perendaman beras ketan selama 12 jam

Formula yang digunakan untuk panel organoleptic sama dengan yang digunakan untuk uji kerenyahan rengginang yaitu dengan lama perendaman beras ketan selama 6 jam. Karena berdasarkan perhitungan lanjutan Tukey lama perendaman 6 jam merupakan dosis yang paling optimal terhadap kerenyahan rengginang.

Dari hasil panel organoleptic uji kesukaan diolah dengan metode perbandingan eksponensial untuk mendapatkan nilai MPE dan dapat diketahui lama perendaman yang paling tepat. Dari hasil perhitungan didapatkan:
a) Sampel A = lama perendaman 6 jam $=596.234,01$
b) Sampel B = lama perendaman $9 \mathrm{jam}$

$$
=114.628,17
$$
c) Sampel C = lama perendaman $12 \mathrm{jam}$ $=30.827,92$

Dari hasil tersebut maka lama perendaman terbaik adalah 6 jam karena memiliki nilai MPE yang paling besar yaitu $596.234,01$.

\section{KESIMPULAN DAN SARAN}

1. Kesimpulan

a) Pada perancangan eksperimen dengan metode Anova Satu Arah pada pengujian kerenyahan pada rengginang menyatakan bahwa "lama perendaman beras ketan dalam proses pembuatan rengginang mempengaruhi hasil pengujian kerenyahan pada rengginang". Dari hasil uji lanjutan (Tukey) bahwa lama perendaman 6 jam, 9 jam, dan 12 jam berpengaruh signifikan terhadap kerenyahan rengginang. Dan yang dipilih adalah yang paling kecil yaitu 6 jam.

b) Pemilihan lama perendaman beras ketan terbaik menggunakan sistem pendukung keputusan pendekatan MPE (Metode Perbandingan Eksponensial) pada pembuatan rengginang adalah lama perendaman selama 6 jam dikarenakan memiliki nilai MPE yang paling besar yaitu $596.234,01$.

\section{Saran}

Berdasarkan hasil analisis dan kesimpulan, terdapat beberapa saran yang bisa dipertimbangkan dalam upaya mengoptimalkan penelitian ini, yaitu:

1. Diharapkan menggunakan bahan baku yang berkualitas, bermutu baik, dan fresh supaya dapat menghasilkan finish good yang berkualitas, seperti beras ketan yang langsung dari petani, dikarenakan belum menggunakan bahan kimia.

2. Penjemuran pada suhu yang stabil, supaya rengginang dapat matang dan siap untuk digoreng sesuai dengan waktu yang sudah ditentukan sebelumnya.

\section{DAFTAR PUSTAKA}

Azwar S. 1997. Metode Penelitian. Yogyakarta: Pustaka Pelajar.

Cooper, Donald R., dan Pamela, S. Schindler. 2006. Metode Riset Bisnis, Volume 1. Jakarta : PT Media Global Edukasi.

Fraenkel, Jack. R., and Norman E. Wallen. 2012. How to Design and Evaluate Research in Education 8th Edition. Boston: McGraw-Hill Higher Education.

Ghozali, Imam. 2005. Aplikasi Analisis Multivariate Dengan Program SPSS. Edisi Ketiga. Semarang: Badan Penerbit Universitas Diponegoro.

Ghozali, Imam. 2009. Aplikasi Analisis Multivariate dengan Program SPSS. Semarang: UNDIP.

Hicks C. R. 1982, Fundamental Consepts in the Design of Eksperiment $3^{\text {rd }}$ edition, New York: Holt-Saunders International Editions.

Marimin dan Maghfiroh N. 2010. Aplikasi Teknik Pengambilan Keputusan dalam Manajemen Rantaii Pasok. Bogor: Penerbit IPB Press

Milliken, G. A., \& Johnson, D. E. (2009). Analysis of Messy Data volume 1 Designed Experiments Second Edition. New Jersey: Taylor \& Francis Group.

Mintzberg H. 1973. The Natural of Managerial Work. New York: Harper Collins.

Montgomery D.C. 2005. Design and Analysis of Exsperiment, $6^{\text {th }}$ Ed. John Wiley \& Sons. New York. 
Saptariana. 2014. Peningkatan Kualitas Produksi Rengginang Ketan Menggunakan Teknologi Pengering Buatan. Semarang: UNS.

Sukardi. 2003. Metodologi Penelitian Pendidikan (Kompetensi dan Praktiknya). Jakarta : Bumi Aksara.

Sitinjak, Tumpal JR \& Sugiarto. 2006. LISREL. Yogyakarta: Graha Ilmu

Singarimbun, Masri dan Effendi, Sofyan. 2001. Metode Penelitiam Survei. Jakarta: LP3ES.

Suryabrata, Sumadi. 2006. Metodologi Penelitian, Jakarta: PT. Raja Grafindo Persada.
Suryadi K. dan Ramdhani M.A. 2002. Sistem Pendukung Keputusan. PT. Remaja Rosda Karya. Bandung.

Subiyanto I. 2000. Metode Penelitian Managemen dan Akuntansi. Yogyakarta: UPP AMP YKPN

Tarwotjo, Soejoeti. 2008. Dasar-Dasar Gizi Kuliner. Jakarta: Grasindo.

Walizer, Michael. H., \& Wienir, Paul. R., 1987. Metode dan Analisis Penelitian: Mencari Hubungan. Jakarta: Erlangga.

Warintek. 2001. Teknologi Tepat Guna Pengolahan Pangan: Rengginang. http://www.warintek.ristek.go.id (Diakses tanggal 1 Juni 2019) 